\title{
ART EDUCATION IN PAKISTAN: COLONIAL LEGACY AND CHALLENGES OF $21{ }^{\text {st }}$ CENTURY
}

\author{
Rafya Tahir \\ Art \& Design Department. College of Home Economics, Lahore, Pakistan
}

Email: raafyatahir@gmail.com

\begin{abstract}
Education in the Subcontinent prior to British takeover was mostly informal. Institutionalized formal Education in the region was introduced by the British rulers in 19th century. Pakistan inherited the system which was divided at school, college and university levels. The presence of art in this system is indebted to the British who opened art colleges and departments in the university later on inherited by Pakistan. The tradition of art teaching in the subcontinent was based on apprenticeship and personal coaching. This trend was duly changed in the British period and presently art education is available to every person interested in the subject. This analytical paper focuses on the relevancy of contemporary art education with Pakistani society and the challenges faced by art institutions in the 21st century. Pre- independence and post-independence institutes of higher art education in Pakistan will be analyzed to derive conclusion.
\end{abstract}

Keywords: Art Education, Colonial legacy, apprenticeship, art teaching in Pakistan

\section{Introduction}

Twenty first century saw the emergence of varied trends in cultural economy, globalization, creative industries and visual culture, art based trade and most of all a constantly expanding virtual world. In the face of this fast changing world, art (because of its intrinsic and extrinsic qualities) assumed new importance in the socio cultural context. Art Education today has grown from drawing and painting to include ceramics, weaving, textiles, and computer arts and crafts. The British rule in the subcontinent affected many facets of regional life. After seventy years of independence, the colonial legacy can still be felt in many social and cultural aspects of Pakistan and art education reflects many traditions from the past both positive and some not so positive. Contemporary art education in Pakistan is under the influence of colonial art theories and teaching practices and there exists a need to incorporate changes in both curriculum and practices to meet the challenges of twenty first century.

At the time of independence, Pakistan inherited one university and one Art College, both located in Lahore. Today there are more than one hundred and eighty public and private sector universities in Pakistan, and three art colleges whereas departments of art are operating in almost all universities (Higher Education Commission, 2017). Art as a field of formal study is considered a colonial legacy, for earlier the art traditions in Pakistan and India were rooted in craft technologies. Presently fifty three universities and colleges are offering degrees in Arts and Arts related fields (Eduvision, 2017). The Higher Education Commission in its draft of revised curriculum for Fine Arts, realized two important aspects of art education in Pakistan: art has been taught according to the Western way of teaching and that traditional arts and crafts have been sidelined (Khan, 2014). In spite of this admission, a workable solution has not been suggested by the Higher Education Commission, which results on the continuation of pedagogies from the past.

The structure of education in Pakistan is composed of school, college and university levels. It can be further categorized as primary, secondary, higher secondary, undergraduate and postgraduate stages. Art as a free activity is offered at primary and secondary levels both in public and private sector institutions. At higher secondary level it is offered mainly in female colleges with the exception of one or two male colleges (Colleges, 
2017). At undergraduate and postgraduate levels specialized art schools offer education in art both in public and private sectors. This paper explores the beginning of art education in Pakistan and the curriculum which is offered at higher secondary, undergraduate and postgraduate levels. For this purpose the contents of the syllabus have been studied and the teaching practices analyzed. The results are presented in descriptive form. At higher secondary level standardized syllabus is offered, at undergraduate and postgraduate levels the syllabus differs from institution to institution. There is no standardization of teaching practices. This paper is divided in sections. The first section deals with a brief description of pre-independence heritage. Moreover it throws light on the existing pattern of art training before the arrival of British in the subcontinent. The next section explores the growth of art education in Britain in nineteenth and twentieth centuries. It then moves to discuss the current situation of art education in Pakistan. The colonial influences on art education in Pakistan and their impact on present day art students is discussed and conclusions drawn. The research relies on primary and secondary sources, personal experiences and field surveys.

Art education is a field of study with multiple layers and a broad scope. It provides opportunities for personal, cultural and educational development. At higher education level it provides prospects for research, aesthetic development; combines history of human development and contributes in the overall social growth of culture and civilization.

Creating art is imbedded in human consciousness. Starting from the cave dwellers till present times, art has remained an integral part of human civilizations. However, the impulse of creating art has taken multiple shapes in the form of concepts, materials and techniques. Contrasting the past, when art was mainly an individual activity, in present times, the creation of art has assumed a complex and systematic procedure disseminated through organized art institutes. From isolated individual activity, art has become a phenomenon which can be collectively learned from well-established institutions and trained teachers. Presently the paradox of art education involves art creation, art research, art psychology, art criticism, art history, art therapy and art teaching. The subject itself has been evolving since the time of cave dwellers. While the cave artists employed only drawing and painting for their expressions, after about 20,000 years the modern artist has scores of subjects which can be studied under the general umbrella of Art \& Design.

To assess the level and scope of art in Pakistan is a taxing job because of its checkered history in the region and the diversity it offers. Art education in the West emerged as a field of study in late eighteenth century after the Industrial Revolution. Early twentieth century saw the rise of well-organized art institutions. That was the time when the importance of this subject was realized in early childhood education, linking it with cognitive and motor development of children (D.Gaitskell, 1975). Institutions offering art at higher education level were not many, but it was soon realized that the training of art should be made accessible to general public.

The nineteenth century witnessed scientific and social revolutions at an accelerated pace. The changing environment in Europe also affected the field of art. From artist's studios, where talented youngsters were taken as apprentices, art academies emerged in the sixteenth century Italy and gradually assumed an early form of art school. The trend of opening art academies spread to other parts of Europe (Academic Art, 2017). With the expansion of colonial powers the social and scientific ideologies were taken to other continents. Britain expanded its colonial power and thus became a major player in implementing its ideas in the lands it ruled. Since the seventeenth century, the training of artists in academies comprised learning of anatomy and geometry. In England systematized higher art education emerged in the form of Royal College of Art (1837), The Slade School of Art (1868) and others, which offered courses to the students who wanted to learn the basics of art.

The region of subcontinent became a receptor of social and educational changes in Britain during the colonial period. From a meager inheritance in terms of educational institutes, Pakistan rapidly developed a system of education generally and art education particularly. But the system was developed on selected colonial approaches which mainly revolved around the teaching and learning of drawing and painting in academic style. 
Keeping in mind the economic conditions of Pakistan, a lot can be gained by reviving the art and industry partnership introduced by the British, but discarded later on in post-independence era.

\section{Pre Independence Heritage}

The Subcontinent has a rich arts and craft heritage. The region is home to some Neolithic civilizations like Mehr Garh in Balochistan, Pakistan, Indus Valley Civilization in Sind, Pakistan and later cultures such as Gandhara in North West Pakistan. These early cultures display a distinguished aesthetic sense and produced some very fine specimens of art and craft. After sixth century A.D, the blooming of Hindu and Jain art and much later from thirteenth century onwards Sultanate, and Mughal art showcase the rich tradition of teaching and learning of art and craft. It also establishes a fact that learning about art, teaching art techniques, and creation of art is not new to this region. Furthermore, this area produced some of the finest art works in terms of stone sculpture, miniature painting, calligraphy and applied arts. Contrary to the common perception, that art teaching did not exist here prior to the British occupation, it not only existed here but also was known for the quality of its aesthetically pleasing utilitarian products and architectural monuments. This proves that education in arts always existed in the subcontinent, though it may differ in its methodology. Even in present day Pakistan and India there are families called gharaana in Urdu, who teach their artistic crafts to younger generations for the continuation of their skills. The most common practice of art teaching occurs out of schools and relies on non-formal strategies, like apprenticeship, coaching and training. This type of teaching was common before the formal schools in subcontinent and exists even in this time when both Pakistan and India have a strong formal school system in their respective countries.

Prior to the arrival of Mughals in subcontinent the art of painting was limited to fresco paintings and palm leaf paintings. The Mughal period (1526) saw the emergence of new aesthetic ideals and an accelerated production of art and craft activities. Education developed with a fresh facet during that period and developed strong interaction between Indian and Islamic traditions in all fields of knowledge like theology, religion, philosophy, fine arts, painting, architecture, mathematics, medicine and astronomy (V.K.Maheshwari, 2017). They opened maktabs (elementary schools) where languages and mathematics were taught. Moreover they encouraged opening of libraries at court level which housed manuscripts of diverse subjects. A survey of literary sources and biographies of Mughal emperors reveal that there was an appreciation for funoon (artworks) among the elite of this region. The patrons of art belonged to the upper classes as well as the religious institutions. Besides the production of manuscripts, the makers of Hindu, Jain and Budhist temples, and the creators of Muslim mosques, focused on the elaborate ornamentation of their monuments. This required a strong body of trained artists and craftsmen who could comply with the demands of their patrons. This indicates to the fact that there existed a strong tradition of art training which was always able to provide the trained workforce. Mughal emperor Akbar is known for his atelier where skilled artists worked to produce album paintings and other forms of design. The production of art was a coordinated activity with many skilled artists, illuminators and calligraphers working under an ustad (teacher) in a well-established scriptorium (Rogers, 2006).

The arts of Mughal time were closely linked with industry, as ornamentation designs became an integral part of carpets, metal work, pottery, manuscript illumination and textiles. From literary accounts it can be inferred that in such a scriptorium, the ambience was of teaching and learning and can be termed as an art school, where teaching was mainly technique driven. This type of art teaching involved chaapa kari (tracing), naqashi (design work for illumination and ornamentation), khattati (calligraphi), wasli making (paper making for painting), musawari (painting) jild sazi (binding) and colour making and mixing

With the decline of Mughal Empire, and advent of British rule (1858) the local practice of art production gradually waned. However the new rulers of subcontinent were duly impressed with the quality of arts and crafts produced here and were motivated to use the local potential for their own manufacturing sector. In the early twentieth century, Britishers encouraged the artists working under the influence of European art. In such 
an environment there emerged a group of artists who reacted to this trend and tried to reclaim their artistic roots in their paintings (Ali S. 2000). Such nationalists movements were mostly individual efforts as there were no systemized pro-Indian arts education in the region at the time, in fact the few schools opened in the subcontinent were based on promoting the British values.

\section{British Art Education in $19^{\text {th }}$ and $20^{\text {th }}$ centuries}

Art practices in nineteenth century England underwent rapid changes. Acknowledgement of art at state level, as a worthwhile field of study can be linked with the agricultural and economic crisis which hit England in 1940. The state of economic depression pushed the policy makers to develop an art based economy which demanded an art literate work force for the manufacturing of British goods with good taste throughout the Empire (Kerry Freedman, 1998).

The Victorian age consolidated art education which was based on a systematic curriculum spread over twenty three stages; starting with elementary and moved on with complex assignments. The students who failed to move upwards returned to teach in the elementary schools compromising the quality of art teaching. The students were exposed to elaborate drawing activities dominated by copying and shading which provided sufficient skills to be absorbed in art related industry. The programme was aimed at developing graphic techniques which cultivated an appreciation for the patterning and ornamentation in diverse areas of the Empire (Kerry Freedman, 1998). It was with this goal that first art schools were opened in the subcontinent.

In nineteenth century Europe, Art education was linked with the psychological development of students from a very young age and it relied on expression driven techniques (D.Gaitskell, 1975). In England on the other hand, it started from elementary stage and relied on technique driven approach. The failure of agricultural economy since the mid nineteenth century pushed the policy makers to boost the manufacturing sector. This provided art education the space it needed to grow (Freedman, 2003).

British formal art education in the nineteenth century was based on the values of academic art, which was learned through rigorous training in replication of old master's work, and studying anatomy in strict conformity. Victorian age industrialized art education and gave way to free arm drawing in the early twentieth century, but still remained connected with industry and manufacturing. The two educational policies in 1914 and 1918 in Britain elevated the status of art from an industrial subject to a more academic one (Kerry Freedman, 1998).

The profound impact of academic art in Europe can be seen in the British art education strategies. The rules for the creation of art work laid down by art academies were; adherence to rationality, representational imagery with historic content and having a strong message (Academic Art, 2017). The philosophy behind academic art played a major role in shaping the school curriculum in Europe generally and Britain particularly. In early twentieth century, the strict rules were relaxed a bit in Britain and free arm drawing was promoted. Since this time period is parallel to British rule in India, the impact of such changes was bound to be felt in not only the opening of art schools, but in the teaching strategies as well.

Art education in the twentieth century, assumed a new outlook with psychologists and educationists joining hands to highlight the hidden qualities of this subject not previously explored. Furthermore, the subject itself provided multiple facets for intellectual inquiry. The growing interest in art invited experts to explore its psychological, social, educational and economic values. The time period saw the rise of two approaches in art curriculum which can be termed as the creative approach applied at school level and technical/functional approach applied at higher level.

In England, Art education witnessed fracturing in the form of art for children and adults. While female teachers with basic knowledge of art were hired to teach children through free arm drawing, male teachers were thought suitable for technique based drawing for adult teaching. Both fractions were called Art Teachers Guild (ATG) 
and the National Society of Art Masters (NSAM) respectively (Kerry Freedman, 1998). After 1940 British art education absorbed many changes, but in the subcontinent these values were transmitted and firmly rooted which affected the model of art education in Pakistan for seventy years. The art institutions operating in India prior to the partition of the subcontinent emphasized conventional drawing techniques including observational and technical methods. The local artists were influenced by new teaching methods and such Indo-Classical art was promoted at government level. Artists like Ravi Verma and Allh Buksh were acknowledged for classical value in their art. In such an environment there emerged a group of resisting artists who wanted to uphold the native artistic values. But their efforts were largely at individual level and such thoughts were not absorbed in the curriculum of art till 1947. The rich craft traditions of this region were not made a part of the art curriculum in Fine Art Department, University of the Punjab, but at Mayo School of Arts. The only link with the local art traditions included copying of designs on Mughal monuments. The craft techniques and an appreciation of local artists was not a part of any art programme.

\section{Art Education in Pakistan}

Art in Pakistan is a growing field, but at the time of its inception things were quite different. Pre-independence art in the region revolved around colonialism and nationalism. Local artistic practice was dominated by the art of miniature painting. The two artists from early twentieth century, known for their distinct styles are Abdur Rehman Chughtai and Allah Bakhsh. One worked in the old tradition of miniature painting and the other was under the influence of colonial academic art.

The faculty of art institutes opened during the colonial period inculcated classical values. Such exposure brought the local artists face to face with a style which was opposite to their art. Art traditions in India involved miniature painting, sculpture, calligraphy and crafts. Instead of observational drawing, local artists drew from imagination according to pre-determined rules. The new art schools offered a method based on observational drawing. This method was also prevalent in Britain at the time.

Meanwhile The University of the Punjab, Lahore, opened the Department of Fine Art (1940) headed by Mrs.Anna Molka Ahmad which inculcated the academic training to mostly female students (Ali S. A., 1984). The existence of Mayo School of Arts since 1875, just opposite to Department of Fine Arts on the Mall, Lahore, indicates the interest of British rulers in establishing art education in the subcontinent. This section of the paper aims to throw light on the art trends prevalent at the time of independence, the art curriculum of the time, and the present day situation in terms of access to art education in the country, and the models of art teaching at higher art education level.

The two institutions had different paradigms. The earlier was based on the model of technical art education which was the main trend in Britain in nineteenth century, whereas the later was formulated on the blend of humanistic and academic art educational model rooted in the intellectual content of art which was the basis of art education in Britain in early twentieth century. The Mayo School of Arts worked independently, however the department in Punjab University was soon linked with school and college art courses which provided a rational base for the students to pursue a higher degree in arts. The latter also provided a curriculum framework which contributed not only in the personal development of artists but equipped the graduates to join art teaching as a profession.

The Mayo School of Arts in Lahore (National College of Arts, 1875) on the other hand was an institution which upheld the value of arts through technical drawing which was associated with industrial arts. From 1875 onwards, the students in Mayo School of Arts, learned drawing and design through free arm practice and geometrical design, along with mechanics and physics implemented through workshops for manufacturing (Official Chronicle of Mayo School of Art, 2003). The graduates of this institution enjoyed a successful career in industry and manufacturing sectors till 1958, when it was declared a college and called National College of Arts. This paradigm shift brought changes in the curriculum which blended the courses of both arts and design 
along with theoretical content. Since 1958, the college has shown consistent growth in terms of degrees offered, the curriculum base and the professional opportunities it provides. Today it offers Bachelor degrees in Fine Arts, Design (Textile Design, Graphic Design, Communication Design, Ceramic Design) and Architecture. It also offers higher degrees in Masters/M.Phil. programmes, which are research based and has opened venues in academic professions.

The curriculum of Fine Art Department at University of the Punjab, included two main components; theory and practical. The theory included study of Western art history from primitive till modern times with an emphasis on the study of classical Greco Roman art. This was reinstated in practical with focus on observational drawings with subjects ranging from study of anatomy, life drawing, and still life to landscape (Ahmad, 1957). This put this institute in the lead which produced art teachers for later times. Graduates of this institution not only contributed in teaching art but also became leaders who helped in opening such departments in the new universities after the birth of Pakistan. The Department changed its name to Art \& Design and started its M.Phil./Ph.D. programme in 2003. This programme offers students to pursue research based degrees which has opened new vistas for the graduates. The curriculum at this institution shows rapid growth with offering of Masters Degrees in varied fields of arts and design. Presently it offers degrees in Bachelors in Fine Arts, and Masters in Fine Arts, including varied subjects like Fine Arts, Textile Design, Sculpture and Architecture.

The Department of Fine Arts was started in Punjab University, Lahore for college girls wishing to study art as an elective subject in intermediate and B.A. examinations. The students who joined these classes had no prior training of drawing, painting and art history. The University believed in intellectual growth of learners. With this aim BA classes were started in June 1942, MA Fine Arts in 1955 and BFA and MFA Graphic Design and Painting were initiated in 1964. These academic art courses provided a foundation for the later art education in Pakistan. (Ahmad 64). Later on the opening of various colleges in urban centers of Pakistan started offering Fine Arts in higher secondary or intermediate level. It is at this level that teaching of art is still under the influence of colonial practices, but at higher levels non-inclusion of local artistic traditions can also be termed as colonial legacy.

\section{Colonial Legacy and Challenges of $21^{\text {st }}$ century}

The development in the subcontinent during the colonial period has had a long lasting impact on physical and social structure of this region. In the education sector, standardized formal education from school to university level is the biggest achievement of this period as in previous time periods it was not standardized and was mostly religious (V.K.Maheshwari, 2017). Prior to the British period the teaching of art was done through ateliers which was accessible to adult artists (Rogers, 2006). Today art is accepted as a field of study which has potential for psychological, intellectual, social, creative and economic growth. Formal art education for interested students was indeed a success of colonial period. After the independence the opening of art colleges and art departments saw immense growth but remained rooted in its colonial past in terms of teaching methods and a tilt towards western art history, which emerged from academic art in Britain. The technique driven method and strict adherence to traditions is still the core of art education in Pakistan at intermediate or higher secondary level which has bound art teaching in conservative boundaries. At undergraduate and post graduate levels art education is quite liberated and is idea driven where students are encouraged to explore art with more contemporary teaching approaches. The colonial legacy can be traced in standardized art curriculum, academic style of teaching, linking art with manufacturing sector and a strict adherence to western models of art education. The local arts and crafts are marginalized and students fail to develop an appreciation for them.

\section{Conclusions}

The main conclusion of this paper is that the field of art education (although being a colonial legacy) has positively influenced Pakistan, but the conservative pedagogies need to be replaced with more modern approaches which are relevant to present day social and economic conditions. The rapid growth of media and 
technology in twenty first century has made globalization a threat to cultural identities. Modified art courses with the inclusion of content based on local art history and craft traditions can help in preserving the cultural identity and boosting the local arts and crafts through research and student exposure. The revival of art and industry linkage is also needed in Pakistan to enhance art based manufacturing both for local and foreign markets. This colonial strategy has been ignored with the passage of time, and with its revival, Pakistan can benefit immensely. It is also concluded that in present day constantly evolving society, a multi-disciplinary approach instead of technique and medium specific strategy should be adopted. This can help the learners to relate their knowledge with real life situations where more economic benefits can be reaped.

\section{References}

Ahmad, A. M., 1957. Exhibition of Painting \& Sculpture, Lahore: Punjab University Press.

Ali, S., 2000. Painters of Pakistan. Islamabad: National Book Foundation.

Ali, S., 2008. Journey of the Spirit. Karachi: Foundation for Museum of Modern Art.

Ali, S. A., 1984. An Artist; an Institution. Islamabad: Idara Saqafat e-Pakistan.

Anon., 2003. Official Chronicle of Mayo School of Art. Lahore: National College of Arts.

Anon., 2016. Uslegal. [Online]

Available at: www.uslegal.com

Anon., 2017. Academic Art. [Online]

Available at: www.visual-arts-cork.com

Anon., 2017. Eduvision. [Online]

Available at: www.eduvision.edu.pk

Anon., 2017. Higher Education Commission. [Online]

Available at: www.hec.gov.pk

Colleges, D., 2017. Number of Colleges in Punjab [Interview] (25 August 2017).

D.Gaitskell, C., 1975. Children and their Art: Methods for the Elementary School. New York: Harcourt Berace Jovanovich, INC.

Fleming, M., 2010. Arts in Education \& Creativity: A Literature Review. Newcastle: Arts Council England.

Freedman, K., 2003. Teaching Visual Culture. New York: National Art Education Association.

Kerry Freedman, F. H., 1998. Curriculum, Culture and Art Education: Comparative Perspective. New York: State University of New York Press.

Khan, M. S. A., 2014. The Changing Perspectives of Art in Pakistan. Peshawar, University of Peshawar.

Rogers, J., 2006. Mughal Miniatures. London: The British Museum Press.

Smith, P., 1996. The History of American Art Education. Learning About Art in American Schools. London: Greenwood Press.

V.K.Maheshwari, 2017. Education during Medieval Period in India. [Online]

Available at: www.vkmaheshwari.com 